\title{
Global citizenship in teacher education: a critical framing and Australian curriculum case study
}

\begin{abstract}
Teachers are increasingly framed as global civic professionals with a set of dispositions, knowledges and skills for global citizenship. This rationale must also go beyond neoliberal framing of global citizenship as an employability skill set or commodity. There is a social justice imperative to engage pre-service teachers in teacher education curriculum approaches that foster cultural understandings of 'self' and 'other' and how such understandings shape teachers' work. This paper presents a theoretical framing of culture and the intersecting spheres of the local-global citizen and how these frame teacher education. Significant findings include understanding the complex intersections of global education, citizenship education and cosmopolitan education invoked in international frames, national policy borrowing and curriculum change. I then use a case study of a specific Australian teacher education course to highlight pre-service teacher perspectives on global citizenship and an example of how students experienced service learning as a curriculum response in teacher education. The curriculum case study illustrates the transformative potential and challenges of experiential learning in teacher education, particularly as a catalyst and stimulus for dialogue and reflection on global citizenship.
\end{abstract}

Keywords: Global Citizenship, Teacher Education, Cultural Education, Cosmopolitan Learning, Service-Learning

\section{Zusammenfassung}

Lehrkräfte werden zunehmend als Fachleute für "global citizenship" eingestuft und ihnen werden dazu eine Reihe an Dispositionen, Wissen und Fähigkeiten zugeschrieben. Begründungen diesbezüglich müssen auch über den neoliberalen Rahmen von global citizenship als Beschäftigungsfähigkeit oder Ware hinausgehen. Es ist ein Gebot der sozialen Gerechtigkeit, Curricula für angehende Lehrkräfte einzusetzen, die dazu beitragen, ein kulturelles Verständnis für das „ich“ und das „andere“ zu fördern und zu verdeutlichen, wie ein diesbezügliches Verständnis die Arbeit von Lehrkräften prägt. In diesem Beitrag wird ein theoretischer Rahmen für Kultur und die sich überschneidenden Sphären lo- kal-globaler Bürger/-innen vorgestellt und wie dies Lehrerbildung rahmt. Zentrale Ergebnisse umfassen das Verständnis der komplexen Schnittstellen von globalem Lernen, staatsbürgerlicher Bildung und weltbürgerlichem Lernen im internationalen Feld, im Rahmen nationaler Politiken und auf der Ebene von Änderungen des Curriculums. Anschließend wird anhand einer Fallstudie eines ausgewählten australischen Lehrerausbildungskurses die Perspektive angehender Lehrkräfte auf global citizenship aufgezeigt und ein Beispiel referiert, inwiefern Studierende erfahrungsorientiertes Service-Learning als eine Antwort auf das Curriculum in der Lehrerbildung erleben. Die Fallstudie veranschaulicht das transformative Potenzial und die Herausforderungen des erfahrungsorientierten Lernens in der Lehrerbildung, insbesondere als Katalysator und Impulsgeber für den Dialog und die Reflexion über global citizenship.

Schlüsselworte: Global Citizenship, Lehrerausbildung, Kulturelle Bildung, Weltbürgerliches Lernen, Service-Learning

\section{Introduction: the teacher as local-global citizen and cultural worker}

Teachers are tasked with enacting the broad civic goals of education - developing active, informed citizens. It is an imperative therefore of teacher education to explore teaching as cultural and civic work and incorporate pedagogies that enable and foster knowledge of self and 'place' and the significance of individual and collective identities that shape the curriculum locally, nationally, regionally and globally. This paper focuses on teacher education for global citizenship, drawing on international theorising and curriculum trends and then specific case study data from teacher education curriculum in Australia.

Firstly, there is a need to explore the theoretical framing of the discourses of global education, global citizenship and the implications these have for positioning the cultural 'capabilities' and civic role of teachers. Discourses of the cultural capacities of teachers can be somewhat narrowly focused on responding 'the 
other' or broadly conceived so as to focus on the understandings of self, that provide a lens for teaching and shape how teachers come to their complex relational and contextual work. Global perspectives take up distinct local, national and regional lens because as Schweisfurth suggests "even education which aims at creating global perspective in learners is a distinctly culture-bound exercise" (2006, p. 42).

Singh, Kenway and Apple (2005) propose that the global analytic is invariably adopted across a range of theoretical and disciplinary orientations. Globalisation and internationalisation are used in relation to student cohorts, curriculum knowledge, capabilities and broad aims and rationales for educating for connected global futures. The terms internationalisation, international mindedness, multicultural education, global education and globalisation can be conflated or can be seen as quite distinct (even within different groups within an educational institution). Increasingly this century the 'curricular global turn' has advocated for "more global orientation in its pedagogy and curriculum and to equip children and young people with the knowledge, skills and dispositions that will make them more aware of, and engaged with, global issues and phenomena” (Mannion, Biesta, Priestley \& Ross, 2010, p. 443). In this paper I am particularly focused on these knowledges, skills and dispositions of global citizenship and implications for cultural literacy in teacher education.

As a set of typologies that form an analytical frame for the case study that follows, Martin and Pirbhai-Illich (2015, p. 138) identify four ideologies for global citizenship education:

- Neo-liberal: to produce citizens who are economically productive, mobile and able to successfully compete in a global economy

- Classical: to produce national citizens who have gained cultural knowledge and are able to be nationally-integrated autonomous subjects

- Liberal: to produce citizens who are personally autonomous, compassionate, able to think for themselves and to act for the betterment of the world

- Critical: to produce citizens who are oriented towards change of a radical kind, being critical of systems that reproduce injustice and seeking to destabilise the status quo

These four typologies highlight dominant discourses across the spectrum of cultural education where critical global citizenship would be aligned with "multicultural education conceptualized as a political project of social justice that embraces a diverse public, and that links local with global struggles for equity and human rights, offers a potential counter-narrative to neoliberal education, and a rich framework for considering citizenship" (Sleeter, 2014, p. 85). This analytical framing somewhat oversimplifies the local and global didactic that shapes the cultural experiences of the citizen.

Cosmopolitan citizenship is a concept that links the local, the national, and the global. As Osler and Starkey (2005) argue, it allows us to conceive of citizenship as a status, a feeling, and a practice at all levels, from the local to the global (Osler, 2011). Risvi's (2009) notion of cosmopolitan learning is critical of essentialist notions of culture and argues that learning about culture should emphasise historicity, criticality, relationally and reflexivity. Some neoliberal and accountability framing of teachers' work positions culture in potentially essentialised ways. Risvi aligns with Beck's notion of cosmopolitanism that "puts the negotiation of contradictory cultural experiences into the centre of activities: in the political, the economic, the scientific, and the social" (Beck, 2002, p.18). Social consciousness and the "intersection and interaction with the local and personal” (Clifford, 2009, p. $135)$ is a discourse of 'glocal' citizenship. The latter recognises that the local is not subsumed by a universal global consciousness but rather that the two are interconnected where the global is constructed by and dependent on many 'locals' (Salter \& Halbert, 2017, p. 3).

Theorising the 'glocal' citizen and the possibilities of cosmopolitan learning has implications for curriculum design. One response, is cultural education that takes up critical pedagogies and transformative learning theories draws on intersections of the work of Dewey (1944), Mezirow (1991, 2000, 2003), and Freire $(1970,1986)$. This theoretical foundation contends that changes to frames of reference and expectations combined with critical reflection on experiences leads to transformative learning and changes in worldview (Dewey, 1944). These frames of reference and critical reflections are contextualised in terms of teacher education in Australia and then explored through a case study of students' perspectives and experiences.

\section{Teacher Education for Global Citizenship in Australia}

In line with the global curricular turn, Australian universities and teacher educators have internationalised the curriculum. However there are tensions in the discourses of global citizenship shaped by supranational organisations, national policy framing of global and regional engagement, teacher performance measures and translation of national curriculum.

The initial wave of globalisation was the sponsored mobility of students, then came a second wave of international recruitment. Universities Australia (2013) refers to a 'third wave' of globalisation in higher education, emphasising long-term sustainable, reciprocal partnerships built on cross-institutional activity and globalised curriculum. Nationally funded mobility programs enable and privilege regional mobility in the Asia Pacific, in part based on neoliberal economic rationales of developing social networks and enabling productivity (Department of Foreign Affairs and Trade, n.d.). While European citizenship education navigates nation-state, regional European Union and global spheres, Australia aspires to "know Asia", a somewhat problematic othering of Asia but also strategically enabling mobility for cultural exchange (Salter, 2014). These policies of global engagement in higher education enable curriculum responses that leverage neoliberal rationales and seek to enact critical citizenship education with understandings of culture as relational and reflexive.

Within teacher education courses, national policies and professional standards both enable and constrain the imperatives for educating teachers as culturally literate global citizens. Teacher educators "are navigating the many discursive practices in educating about and for culture and there are slippages in our positioning of culture as we work within and beyond existing policies and systemic practices" (Halbert \& Chigeza, 2015, p. 159). Regulatory frameworks that focus on teachers' knowledge and skills to response to 'diversity' in the classroom can essentialise cultural 
education. There is potentially a narrowing of teachers' professional selves to assuring cultural responsiveness to 'other' and little acknowledgement of the complexity of teachers' own global, culturally literate identities as influencing their practice. Reductive interpretation of the professional role of teachers also creates tensions when standards and assessment must balance 'knowledge as problematic' with knowledge as 'known' and assured. "Assuring" professional competencies of teachers across the complex domains becomes problematic (Halbert \& Chigeza, 2015).

Within the realms of higher education policy and teacher education policy there are discourses of global citizenship that are largely aligned with neoliberal rather than cosmopolitan ideals however this agenda can be leveraged to foster dispositions, knowledges and skills for critical global citizenship. I now turn to how such an aim is enacted in one case study and how that curriculum response for fostering local global citizenship sits alongside student perceptions of global citizenship.

\section{Methodology}

This paper draws on data from a larger project reviewed and approved by the lead university's board of research ethics, which investigated the types of community-based learning experiences, curriculum and pedagogy that foster critical global perspectives in diverse university cohorts through local and international experiences (Salter, Halbert, Howard \& Singh, 2018).

In this paper I focus on teacher education using one of the case studies which was a core subject in an initial teacher education degree. The curriculum case study is a service-learning subject, which aimed to cap off the degree and frame intentional learning in a range of wider professional experiences with diverse groups and organisations. The service learning projects require students to undertake a minimum of 50 hours, with a focus on activities that promote social and environmental responsibility, including options for local, national and international experiences. Data for this case was collected through an online survey $(n=28)$ administered in week one of the course, and assessment samples collected and focus groups conducted with staff $(n=4)$ and Pre-service Teachers (PSTs) $(n=5)$. Recruitment for the latter was focused on PSTs that had explicitly engaged with global perspectives through service, in this case a university organised overseas placement in Cambodian non-government schools. The intent of the case study is to enact a curriculum underpinned by critical service learning and critical global citizenship.

Participants were representative of the "Service Learning for Sustainable Futures" cohort and highlight the diverse nature of students that is characteristic of a regional Australian university: mostly mature age (57\% aged $20-30,36 \%$ aged $30+)$, $62 \%$ were first in their family to attend university, $7 \%$ identified as Aboriginal or Torres Strait Islander, 78\% reported living in a remote or regional area prior to attending studies, $64 \%$ had work commitments outside of study and 50\% had caring commitments. Data collection comprised:

- Survey of students to ascertain dispositions to cultural exchange and citizenship and demographic and cultural profile;

- Document analysis of subject materials and resources, focussing on intended and enacted curriculum;

- Focus groups with students to explore their experiences of curriculum enactment; and
- Focus groups of staff to elaborate on intention and enactment of curriculum, and perceived experiences of students.

Data analysis adopted an iterative 'spiralling' approach (Denscombe, 2007; Kvale, 2007) informed by four theoretical frames: Billett's (2011) intended, enacted and experienced curriculum, the Global Citizenship Continuum (Enberg, 2013), Taxonomies of Service Learning (Britt, 2009) and Martin and Pirbhai-Illich's (2015) four ideologies for global citizenship education.

\section{Student perspectives}

The following section analyses some of the ways in which PSTs conceptualised global citizenship. These perspectives illustrate the ways in which various dispositions, knowledges and skills are invoked. A survey was administered to the cohort to ascertain perspectives and dispositions towards cultural education and global citizenship prior to undertaking the subject. Specifically, students were asked "What does being a global citizen mean to you?” ( $\mathrm{N}=27)$. Student responses can be considered on a continuum of liberal through to critical and transformative citizenship. The selection of student perspectives below is discussed with reference to Martin and Pirbhai-Illich's (2015) four typologies, some alignment with cosmopolitan principles, and implications for the curriculum.

One grouping of responses spoke of key dispositions such as "Awareness, Openness, Informed". These were sometimes general and sometimes made distinctions between ones' own culture/s and others' cultures: of all cultures.

Having an awareness and respect for difference. Accepting

I keep myself aware of global events, take a keen interest in people with backgrounds different to my own and keep my views objective to understand what's going on in the world.

These responses illustrate broad liberal citizenship education principles of tolerance and respect with a general disposition to understanding global perspectives through raising ones awareness. Such descriptors also align with neoliberal discourse of cultural competency - understanding and acceptance. One response highlights a 'glocal' consciousness and imaginings of shared humanity:

Being able to appreciate the interconnectedness of different groups of people around the world.

Another grouping of responses were more agentic in not just knowing about but taking up values of responsibility and involvement in 'whole of humanity' issues and challenges, with focus on social justice/inequality/sustainability:

It means to learn about global issues and take action on those issues.

I believe that I am responsible to play a role in advocating for issues which keep a country from moving forward. Eg. Preservation of Cultural Diversity, Sustainable communities and Gender Equity, and Poverty.

I am able to maintain social, work and personal interests and connections to citizens and organisations in countries other than my own. I am also able to contribute in some way to their needs while furthering my own understanding of other cultures and communities.

Being aware of what is happening in the world and taking action to right injustices. 
Sometimes with a focus on intra-personal understanding that aligns with the relationality and criticality of cosmopolitan and critical global citizenship:

Being cognisant of other cultures with beliefs, opinions and values that differ to mine. Therefore, getting to know these cultures before judging is essential - my own belief system should not be applied to others.

In other studies within teacher education students perspectives on global education were similarly varied. A study of UK pre-service teacher attitudes to education for global citizenship found significant differences depending on specialisations (Robbins, Francis \& Elliot, 2003). Correspondingly, in an Australian study Ferguson et al. found that "social justice as a critical perspective was associated with social studies" (Ferguson, Macqueen \& Reynolds, 2013, p. 481). In the same Australian study, "students were primarily focused on their future classroom practices rather than their role in the world more generally" (Ferguson et al. 2013, p. 470). The case study discussed below is a core/mandatory subject for all students regardless of specialisation, previous studies or life experiences. Therefore, students come with varied dispositions for and professional identities to take up cultural experiences and global citizenship.

\section{Student experiences of the curriculum}

In this section I move from students' perspectives of global citizenship to their experiences of a critical service learning placement. I discuss student excerpts that are illustrative of key outcomes/enablers and the challenges of enacting global citizenship education which engages in complex contexts. Across this case, emerging levels of global citizenship were strongest at the level of building knowledge and skills and developing competence and self-efficacy as aresult of service. Notions of social cohesion and relationships as key to global citizenship gained from experience suggests students are developing citizenship and exploring what it means to exist in relation to others in community aligned with liberal civic ideals. The most common development of global citizenship understanding gained from experiences is increased awareness of social factors. The importance of 'relationships' and 'social sustainability', and 'a lot more social cohesion and connectedness' is dominant:

There's a bigger, wider context that you need to remember everybody lives inside and we're all connected through. I'm really big on social cohesion, I think it's vital that we have that if we want our kids to grow up in a future happy world, they really need to know that the teacher really cares about them and wants to get to know them. For me, even though I did go into it with a prior understanding of those kinds of things, it was still beneficial. (PST 7)

The student quote above illustrates a contextual and relational understanding and disposition of care that aligns with a relational view of culture.

Community-based learning experiences such as service learning can facilitate cultural understanding in a local-global dialectic and emphasise the contextual nature of practice. Community based learning in teacher education, as distinct from school based placements, has a focus on widening students' engagement with the communities in which they will work as teachers, as relationships and connections between schools and communities are vital (Salter \& Halbert, 2018). 'Relationship-based pedagogy' (Cain, 2014) and the use of critical reflec- tion before, during and after the experience to make sense of the underlying civic issues and enact their knowledge and skills in ways that demonstrate active local-global citizenship. This was demonstrated from the following student reflection:

Whilst I gained a new perspective of the diffculties including blatant and subtle racism and bias faced by Aboriginal and Torres Strait Islander people, I was able to lend my knowledge and abilities to achieve goals for the organisation and wider community. (survey respondent)

However, such awareness of social justice issues can be overwhelming:

This project left me less motivated to help. It all seems too hard. 50 hours was not enough time to really deliver a project. 50 hours at least is needed for them to get to know me first before I could deliver anything. So I believe in cultural diversity and the importance of cross cultural experiences, but I believe there needs to be more support for students embarking on such a challenging project. (survey respondent)

While the above quote demonstrates a critical consciousness, there is a need for curriculum resources and opportunities for dialogue and support such unbounded learning experiences and challenging independent learning.

\section{Curriculum implications for teacher education}

Global citizenship education "does not fit nicely into any particular curriculum box and must address knowledge, skills and values if it is to be effective" (Ferguson et al., 2013, p. 472). Gaps exist in the development and application of multicultural education frameworks and theories of global literacy within higher education generally. This indicates the importance of integrating intercultural experiences, whether they occur locally or internationally, as a core part of higher education degrees (Walters, Garii \& Walters, 2009) and within well-researched curriculum and pedagogical frameworks. These perspectives are traditionally associated with global mobility, often in the form of student exchanges and study abroad experiences, whose value is clear but that fail to recognise and capitalise on networks of cultural exchange within parochial learning contexts. While the student perspectives in the above section give voice to the various dispositions for citizenship and experiences of service learning in local and global contexts, I now discuss the implications for curriculum development in teacher education that brings 'glocal' learning from the periphery to the core of the curriculum.

There are four domains of best practice that were identified from the larger project across disciplines. These include: 1) intentional design to incorporate critical theories and frameworks for exploring the social justice dimensions of global citizenship, 2) structured orientation to cultural experiences to prepare for 'looking out' beyond familiar contexts and worldviews, 3) facilitated dialogue and critical reflection during and after experiences to make sense of cultural exchanges and potentially troublesome knowledge and positionality and finally 4) a focus on transition and transformation by facilitating reflection on personal and professional links to future careers and actions (Salter, Howard, Halbert \& Singh, 2018).

In designing teacher education courses there are institutional and regulatory frameworks to navigate. As a professional degree, there is usually attention to a developmental sequence 
and application of knowledge for professional readiness, as opposed to some courses where there may be little reference to a cohesive whole (Ferguson et al., 2013). While teacher education is cohesive, programs in Australia tend to favor an integrated approach that can result in token treatment of multicultural education (Watkins, Lean \& Nobel, 2016). An intentional curriculum that is place conscious and utilises critical pedagogies and experiential learning can give attention to knowledge, skills and personal/professional culture as a situated web of significance.

The need for authentic reflective dialogue aligns with an earlier study of a more foundational course in the teacher education program in which we found that "taking up the dominant values and aims within an assessment regime can constrain 'authentic' critical reflection" (Halbert \& Chigeza, 2015, p. 165). A focus on the process of reflection (not assured outcomes) and timely non-linear learning pathways may offer solutions.

\section{Conclusion}

This paper has presented a theoretical framing of culture and the intersecting spheres of the local-global citizen. Freire (1970) proclaimed the need for critique of discursive power and the hegemonic distortion and reappropriation of terms such as 'empowerment', 'community', 'development' and 'active citizenship'. The 'global citizen' can be invoked in critical social justice terms developing critical consciousness and circumstantial awareness (Sleeter \& Grant, 2005) or teachers can be positioned as 'active citizens' in the global economy. The student perspectives explored in this paper show agentic, critical conceptions of the global citizen, alongside more liberal frames.

Teachers as global civic professionals must go beyond neoliberal framing of global citizenship as an employability skills set or commodity that perpetuates hegemonic structures. There is a social justice imperative to engage pre-service teachers in curriculum approaches that foster cultural understandings of 'self' and 'other' as complex constructs and how they shape teachers' work. As the varied experiences of students highlight, there are potentially transformative cultural insights but there are also challenges in supporting learning in unfamiliar contexts, authentic reflection and processing somewhat troublesome knowledge. Teaching is cultural work in the context of many 'glocal' interactions. Hence, curriculum must leverage and navigate neoliberal policy but also take up critical pedagogies and legitimate somewhat messy, relational understandings alongside 'neater' performance measures.

\section{References}

Beck, U. (2002). The Cosmopolitan Society and its Enemies. Theory, Culture \& Society 19(1-2), 17, https://doi.org/10.1177/026327640201900101

Billett, S., (2011). Curriculum and pedagogic bases for effectively integrating practice-based experiences. Office for Learning and Teaching, Department of Education and Training, Australian Government.

Britt, L. (2009). Developing students as learners, citizens, and activists: A proposed taxonomy of service-learning approaches. Proceedings of the Institute for Ethical and Civic Engagement Conference (p. 29). Boulder, CO.

Cain, G. (2014). Service-learning as a way of developing pre-service teachers' knowledge, perceptions, and cultural awareness of Aboriginal education, Thesis. Sydney: University of Notre Dame.

Clifford, V. (2009). Engaging the disciplines in internationalising the curriculum. International Journal for Academic Development, 14(2), 133-143, doi. org/10.1080/13601440902970122

Denscombe, M. (2007). The good research guide: For small-scale social research projects (3rd ed.). Maidenhead, U.K \& New York: Open University Press.
Department of Foreign Affairs and Trade. (n.d.). New Colombo Plan. Access on 13.12.2018 http://dfat.gov.au/people-to-people/new-colombo-plan/Pages/new-colombo-plan.aspx

Dewey, J. (1966). Democracy and education: an introduction to the philosophy of education. New York: The Free Press.

Enberg, M. E. (2013). The influence of study away experiences on global perspective-taking, Journal of College Student Development, 54, 466-480. doi.org/10.1353/ csd.2013.0073

Ferguson Patrick, K., Macqueen, S. \& Reynolds, R. (2014). Preservice teacher perspectives on the importance of global education: world and classroom views, Teachers and Teaching, 20(4), 470-482, doi.org/10.1080/13540602.2014.881639

Freire, P. (1970). Pedagogy of the Oppressed. New York: Continuum.

Halbert, K. \& Chigeza, P. (2015). Navigating Discourses of Cultural Literacy in Teacher Education. Australian Journal of Teacher Education, 4O(11), doi.org/10.14221/ ajte. $2015 \mathrm{v} 40 \mathrm{n} 11.9$

Kvale, S. (2007). Doing interviews. London: Sage Publications, doi. org/10.4135/9781849208963

Lingard, B. \& McGregor, G. (2014). Two contrasting Australian curriculum responses to globalisation: What students should learn or become. The Curriculum Journal, 25(1), 90-110, doi.org/10.1080/09585176.2013.872048

Martin, F. \& Pirbhai-Illich, F. (2015). Service Learning as Post-Colonial Discourse: Active Global Citizenship. In R. Reynolds, D. Bradbery \& J. Brown (Eds.), Contesting and constructing international perspectives in global education. Rotterdam/Bosten/Taipei: SensePublishers.

Mannion, G., Biesta, G., Priestley, M. \& Ross, H. (2011). The global dimension in education and education for global citizenship: genealogy and critique, globalisation, Societies and Education, 9(3-4), 443-456, doi.org/10.1080/14767724.2011.605327

Mezirow, J. (2000). Learning as transformation: critical perspectives on a theory in progress. San Francisco: Jossey-Bass Publishers.

Mezirow, J. (1990). Fostering Critical Reflection in Adulthood. San Francisco: Jossey-Bass Publishers.

Osler, A. (2011). Teacher Interpretations of Citizenship Education: National Identity, Cosmopolitan Ideals, and Political Realities, Journal of Curriculum Studies 43(1), 1-24, doi.org/10.1080/00220272.2010.503245

Rizvi, F. (2009). Towards cosmopolitan learning, Discourse. Studies in the Cultural Politics of Education, 30, 253-268, doi.org/10.1080/01596300903036863

Robbins, M., Francis, L. \& Elliott, E. (2003). Attitudes toward education for global citizenship among trainee teachers, Research in Education, 69, 93-98, doi.org/10.7227/ RIE.69.8

Salter, P. (2014). Knowing Asia: creative policy translation in an Australian school setting, Journal of Education Policy, 29(2), 145-164, doi.org/10.1080/02680939.201 3.794303

Salter, P. \& Halbert, K. (2018). Balancing classroom ready with community ready: enabling agency to engage with community through critical service learning in ITE, Asia-Pacific Journal of Teacher Education, DOI: 10.1080/1359866X.2018.1497771

Salter, P., Howard, E., Halbert, K. \& Singh, M. (2018). Local Global Learning Final Report. Office of Learning and Teaching. Canberra: Australia.

Salter, P. \& Halbert, K. (2017). Constructing the [parochial] global citizen, Globalisation, Societies and Education, 15(5), 694-705, doi.org/10.1080/14767724.2016.126 4290

Schweisfurth, M. (2006). Education for global citizenship: Teacher agency and curricular structure in Ontario schools, Educational Review, 58(1), 41-50, doi. org/10.1080/00131910500352648

Sleeter, C. (2014). Multiculturalism and education for citizenship in a context of neoliberalism, Intercultural Education, 25(2), 85-94, doi.org/10.1080/14675986.2014.8 86357

Sleeter, C. \& Grant, C. (2009). Making choices for multicultural education: Five approaches to race, class and gender (6th ed.). New York: Wiley.

Universities Australia (2013). Global Education. Access on 13.12.2018 https://www. universitiesaustralia.edu.au/global-engagement/Global-Education\#.Wz7d8Kl9jok

Walters, L., Garii, B. \& Walters, T. (2009). Learning globally, teaching locally: Incorporating international exchange and intercultural learning into pre-service teacher training, InterculturalEducation, 20,151-158, doi.org/10.1080/14675980903371050 Watkins, M., Lean, G. \& Noble, G. (2016). Multicultural education: the state of play from an Australian perspective, Race Ethnicity and Education, 19(1), 46-66, doi.org/1 $0.1080 / 13613324.2015 .1013929$

\section{Kelsey Halbert}

is a Senior Lecturer in Education at James Cook University. Kelsey's research and teaching spans values education, citizenship education, History teaching, cultural education and service-learning. 